\title{
Research on Relationship among the Special Education Teachers' Healthy Behavior, Appraisal Support and Depression
}

\author{
Yan Li \\ Leshan Normal University \\ Leshan, China
}

\author{
Hongye Wang* \\ Leshan Normal University \\ Leshan, China
}

\begin{abstract}
The questionnaires are distributed to two hundred and ten special education teachers in the research, in order to investigate the current situation of special education teachers' healthy behavior, appraisal support and depression, the differences of different background variables and discuss the relationship between them. The result shows: 1) the special education teachers' healthy behaviors have significant differences in years of teaching experience, the appraisal supports are obviously different in sex, position and education background, the depression has significant difference in sex, years of teaching experience, the title of class teacher, position and education background; 2) the analysis shows the special education teachers' healthy behavior and the depression have significant negative correlation; the appraisal support and the depression have significant negative correlation; 3 ) results of the structural equation show the special education teachers' healthy behavior and appraisal support play the role of negative prediction on the job burnout. The heath behavior and appraisal support can effectively prevent and relieve the depression of special education teachers, so that we can improve the healthy behavior and appraisal support to prevent and relieve the depression of special education teachers.
\end{abstract}

Keywords—healthy behavior; appraisal support; depression

\section{INTRODUCTION}

As one of the important indicators of social support, the appraisal support refers to the information provided by others that is conducive to the self-evaluation, especially evaluating the ability, effort, attitude or feeling in dealing with things. [1] Any individual is the indispensable member of the social group, paying particular attention to the relational self, especially the evaluation of other important persons. [2] Therefore, the appraisal support in the working environment has an important influence on special education teachers' physical and psychological health. The health behavior refers to the behaviors of people to protect, promote or maintain their health no matter how their perception or actual health is or whether it achieves the goal. Except for the appraisal support and working environment in the working environment, the special education teachers must grasp some controllable healthy behaviors to adjust and maintain the psychological

Fund project: The national education science "the 12th Five-year" plan the priority subject of the Ministry of Education in 2015 "Follow-up Study of the Special Education Promotion Plan (2014-2016)", No.: DGA150225

* Corresponding author: Hongye Wang health. The depression is one of the important indicators of individual's psychological health. According to the research of Biddle, Hardman and Janke, it is easier for people with healthy behaviors to relieve the pressure and feel the happiness. With healthy behaviors, individuals can obtain the positive emotional experience and reduce the pressure.

The psychological health is distinctly important for the front-line special education teachers. They play an important role in students' growth. Their behaviors greatly influence the future of students and the society. Therefore, it is the important premise of students' psychological health to maintain the psychological health of special education teachers. The research takes the depression as the theme and discusses the influence of special education teachers' appraisal support, healthy behaviors on depression, in order to make them keep the good mental state and reduce the risk of occurring depression under the current situation of education that cannot change overnight, as well as under the high demands and expectation of society and parents.

\section{RESEARCH METHODS}

\section{A. Research Object}

The questionnaire survey is conducted for special education teachers in nine rural high schools of Chongqing, Sichuan, Hubei and Gansu through spot testing and non spot testing. We distribute 256 questionnaires and collect 233 (the recovery percent is $91.0 \%$ ), with 210 valid questionnaires. It involves 83 male $(39.5 \%)$ and 127 female $(60.5 \%)$ special education teachers. The basic information of testee is shown in "Table I".

\section{B. Research Tools}

1) Questionnaires about special education teachers' healthy behavior: The research uses the Questionnaire about Healthy Behavior compiled by Lin Youzhen and Wen Qibang, including leisure sports and interpersonal support. The questionnaire uses the likert five score scale to record it from one to five points from "never like this" to "always like this". [6] According to the sample analysis of special education teachers, the questionnaire has good fit index. The inter-item consistency reliability of the whole scale is 0.891 . It shows the questionnaire has good internal consistency reliability. 
TABLE I. BASIC INFORMATION OF TESTEE

\begin{tabular}{llcc}
\hline & & Number & Percent \\
\hline Sex & Male & 83 & $39.5 \%$ \\
& Female & 127 & $60.5 \%$ \\
Experience & Below 5 years & 45 & $21.4 \%$ \\
& 6-10 years & 47 & $22.4 \%$ \\
Monthly & Above 11 years & 118 & $56.2 \%$ \\
income & Below 3000 yuan & 73 & $34.8 \%$ \\
& 3001-4000 yuan & 92 & $43.8 \%$ \\
Marital status & Above 4001 yuan & 45 & $21.4 \%$ \\
& Married & 171 & $81.4 \%$ \\
Education & Unmarried & 39 & $18.6 \%$ \\
background & College degree and below & 61 & $29.0 \%$ \\
& Bachelor degree or above & 149 & $71.0 \%$ \\
Whether is the & Yes & & \\
class teacher & No & 92 & $43.8 \%$ \\
\multirow{2}{*}{ Title } & & 118 & $56.2 \%$ \\
& Special education teacher & & \\
& and administration & 43 & $20.5 \%$ \\
& Special education teacher & 167 & $79.5 \%$ \\
\hline
\end{tabular}

2)Questionnaires about special education teachers' appraisal support: The initial question bank is compiled based on the questionnaire about appraisal support of Yu Minning in the research. Experts' opinions are collected about the appropriateness, accuracy, scientific nature and readability of questions. The questionnaires are formed into the prediction questionnaire after revision. The special education teachers are selected randomly to answer the initial questionnaires. The single-dimensional formal questionnaire with six questions is compiled through modifying, merging and deleting some questions according to the analysis of questions and total points and the exploratory factors. The topics include "win praise and recognition of colleagues", "win the praise and recognition of leaders for the teaching research", "get students' response and affirmation", "see students' achievements" and "win parents' praise" and "acquire the opportunity of engaging in advanced studies". The questionnaire uses the likert five score scale to record it from one to five points from "never like this" to "always like this". The cumulative contribution rate of the analysis results of exploratory factors (KMO $=0.792$, Bartlett's check 683.560 , df $=15$, sig $=0.00$ ) is $60.389 \%$. The inter-item consistency reliability of the whole scale is 0.87 . It shows the questionnaire has good internal consistency reliability.

3) Depression scale for special education teachers: The research uses the Depression Scale compiled by Min-Ning Yu, Yu-Ju Liu, Ren-Hau Li. The questionnaire includes cognition, emotion, body and interpersonal relationship, twenty-two projects in total. The questionnaire uses the likert five score scale to record it from one to five points from "never like this" to "always like this". The higher the score, the more serious the depression is. [7] According to the sample analysis of the special education teachers, the inter-item consistency reliability of the whole scale is 0.92 . The correlation coefficient between different factors is between 0.78 and 0.88 , showing the scale has good internal consistency and structure reliability.

\section{Data Processing and Analysis}

The research data is processed and analyzed by SPSS17.0 and Amos 17.0.

\section{RESEARCH RESULTS}

\section{A. Analysis on the Current Situation of Special Education Teachers' Healthy Behavior, Appraisal Support and Depression}

According to "Table II", the scores of appraisal support and healthy behavior are more than three. It shows the level of them is above the theoretical mid-value. The score of depression is less than three. It shows the level of special education teachers' depression is below the theoretical midvalue. The score of emotion and body dimension is the highest, namely 2.16. The score of cognition dimension is the lowest, namely 1.87 .

TABLE II. MEAN/STANDARD DEVIATION OF SPECIAL EDUCATION TEACHERS' HEALTHY BEHAVIOR, APPRAISAL SUPPORT AND DEPRESSION

\begin{tabular}{llcccccc}
\hline $\begin{array}{l}\text { Leisu } \\
\text { re } \\
\text { sport } \\
\text { s }\end{array}$ & $\begin{array}{c}\text { Interp } \\
\text { ersonal } \\
\text { suppor } \\
\text { t }\end{array}$ & $\begin{array}{c}\text { Apprai } \\
\text { sal } \\
\text { suppor }\end{array}$ & $\begin{array}{c}\text { Cogniti } \\
\text { on }\end{array}$ & $\begin{array}{c}\text { Emoti } \\
\text { on }\end{array}$ & $\begin{array}{c}\text { Bod } \\
\mathbf{y}\end{array}$ & $\begin{array}{c}\text { Interper } \\
\text { sonal } \\
\text { relation } \\
\text { ship }\end{array}$ \\
\hline M & 3.59 & 3.62 & 3.92 & 1.87 & 2.16 & 2.16 & 2.03 \\
SD & 0.97 & 0.97 & 0.79 & 0.56 & 0.78 & 0.80 & 0.93 \\
\hline
\end{tabular}

2) Analysis on the difference of special education teachers' healthy behavior, appraisal support and depression under the demographic variables

a) Analysis on the difference of healthy behavior, appraisal support and depression of male and female special education teachers: Check the independent sample $\mathrm{t}$ with the sex as the independent variable, the healthy behavior, appraisal support and depression as the dependent variables. The results show the scores of male special education teachers in appraisal support, interpersonal support, body and interpersonal relationship are higher than that of the female teachers, but lower than female teachers in leisure sports, emotion and cognitive adaptation. Significant differences exist in appraisal support and body "Table III".

TABLE III. ANALYSIS ON THE DIFFERENCE OF HEALTHY BEHAVIOR,

APPRAISAL SUPPORT AND DEPRESSION OF MALE AND FEMALE SPECIAL EDUCATION TEACHERS

\begin{tabular}{|c|c|c|c|c|c|}
\hline & Sex & $\mathbf{N}$ & M & SD & $\mathbf{t}$ \\
\hline \multirow[t]{2}{*}{ Appraisal support } & Male & 83 & 4.10 & 0.65 & $2.89 * *$ \\
\hline & Female & 127 & 3.80 & 0.85 & \\
\hline \multirow[t]{2}{*}{ Leisure sports } & Male & 83 & 3.58 & 0.99 & -0.147 \\
\hline & Female & 127 & 3.60 & 0.95 & \\
\hline \multirow{2}{*}{$\begin{array}{l}\text { Interpersonal } \\
\text { support }\end{array}$} & Male & 83 & 3.67 & 0.99 & 0.643 \\
\hline & Female & 127 & 3.59 & 0.95 & \\
\hline \multirow[t]{2}{*}{ Cognition } & Male & 83 & 1.83 & 0.59 & 0.846 \\
\hline & Female & 127 & 1.90 & 0.55 & \\
\hline \multirow[t]{2}{*}{ Emotion } & Male & 83 & 2.15 & 0.77 & -0.159 \\
\hline & Female & 127 & 2.17 & 0.78 & \\
\hline \multirow[t]{2}{*}{ Body } & Male & 83 & 2.31 & 0.94 & $2.183^{*}$ \\
\hline & Female & 127 & 2.06 & 0.67 & \\
\hline \multirow{2}{*}{$\begin{array}{l}\text { Interpersonal } \\
\text { relationship }\end{array}$} & Male & 83 & 2.13 & 1.08 & 1.230 \\
\hline & Female & 127 & 1.97 & 0.82 & \\
\hline
\end{tabular}


b) Analysis on the difference of the healthy behavior, appraisal support and depression of special education teachers with different teaching age: Analyze the one-way variance with years of teaching experience as the independent variable, healthy behavior, appraisal support and depression as dependent variables. The results show the emotions of special education teachers with different years of teaching experience are greatly different $(\mathrm{P}<0.01)$. Significant difference exists in leisure sports, cognition and body $(\mathrm{P}<0.05)$. No significant difference exists in appraisal support and the other two dimensions "Table IV".

TABLE IV. ANALYSIS ON THE DIFFERENCE OF THE HEALTHY BEHAVIOR, APPRAISAL SUPPORT AND DEPRESSION OF SPECIAL EDUCATION TEACHERS WITH DIFFERENT TEACHING AGE

\begin{tabular}{|c|c|c|c|c|c|}
\hline & Experience & $\mathbf{N}$ & $\mathbf{M}$ & SD & $\mathbf{F}$ \\
\hline \multirow[t]{3}{*}{ Appraisal support } & Below 5 years & 45 & 3.87 & 0.64 & 1.335 \\
\hline & 6 to 10 years & 47 & 3.79 & 0.83 & \\
\hline & Above 11 years & 118 & 4.00 & 0.82 & \\
\hline \multirow[t]{3}{*}{ Leisure sports } & Below 5 years & 45 & 3.71 & 0.79 & $4.011 *$ \\
\hline & 6 to 10 years & 47 & 3.24 & 1.03 & \\
\hline & Above 11 years & 118 & 3.68 & 0.98 & \\
\hline \multirow{3}{*}{$\begin{array}{l}\text { Interpersonal } \\
\text { support }\end{array}$} & Below 5 years & 45 & 3.52 & 0.88 & 1.189 \\
\hline & 6 to 10 years & 47 & 3.49 & 1.07 & \\
\hline & Above 11 years & 118 & 3.71 & 0.96 & \\
\hline \multirow[t]{3}{*}{ Cognition } & Below 5 years & 45 & 1.76 & 0.48 & $4.228^{*}$ \\
\hline & 6 to 10 years & 47 & 2.07 & 0.63 & \\
\hline & Above 11 years & 118 & 1.86 & 0.55 & \\
\hline \multirow[t]{3}{*}{ Emotion } & Below 5 years & 45 & 1.96 & 0.62 & $6.091 * *$ \\
\hline & 6 to 10 years & 47 & 2.49 & 0.84 & \\
\hline & Above 11 years & 118 & 2.12 & 0.77 & \\
\hline \multirow[t]{3}{*}{ Body } & Below 5 years & 45 & 1.95 & 0.69 & $3.215^{*}$ \\
\hline & 6 to 10 years & 47 & 2.37 & 0.89 & \\
\hline & Above 11 years & 118 & 2.15 & 0.78 & \\
\hline \multirow{3}{*}{$\begin{array}{l}\text { Interpersonal } \\
\text { relationship }\end{array}$} & Below 5 years & 45 & 1.95 & 0.89 & 2.413 \\
\hline & 6 to 10 years & 47 & 2.29 & 0.98 & \\
\hline & Above 11 years & 118 & 1.96 & 0.91 & \\
\hline
\end{tabular}

According to the further analysis on the Post-Hoc test (Tukey HSD), it shows on the cognition, emotion and body, special education teachers with experience of "six to eleven years" get the highest average score, greatly different from special education teachers with experience of "below five years" and "above eleven years" $(\mathrm{P}<0.05)$. Special education teachers with experience of "above eleven" years get the highest score on appraisal support and interpersonal support.

c) Analysis on the difference of healthy behavior, appraisal support and depression of special education teachers with different monthly income: Analyze the one-way variance with monthly income as the independent variable, healthy behavior, appraisal support and depression as the dependent variables. The results show no significant differences exist on the appraisal support, healthy behavior and depression of special education teachers with different monthly income. According to the further analysis on the Post-Hoc test (Tukey HSD), it shows special education teachers with monthly income of "between 3001 and 4000 yuan" get the highest score on appraisal support, interpersonal support and emotion, not significant from special education teachers with monthly income of "below 3000 yuan" and "above 4001 yuan". Special education teachers with monthly income of "above 4001 yuan" get the highest score on leisure sports and body, but not significantly from special education teachers with monthly income of "below 3000 yuan" and "between 3001 and 4000 yuan".

d) Analysis on the difference of healthy behavior, appraisal support and depression of special education teachers with different martial status: Check the independent sample $\mathrm{t}$ with different martial status as the independent variable, healthy behavior, appraisal support and depression as the dependent variables. The results show the married special education teachers get higher scores than the unmarried special education teachers on emotion, appraisal support, interpersonal support and body, get lower scores than then on leisure, cognition and interpersonal relationship, but there is no significant difference.

e) Analysis on the difference of healthy behavior, appraisal support and depression of special education teachers about whether they are class teacher: Check the independent sample $t$ with the possibility of class teacher as the independent variable, the healthy behavior, appraisal support and depression as the dependent variables. The results show special education teachers as class teachers get higher scores than those not serving as class teachers on cognition, emotion, interpersonal relationship and body. Significant differences exist on cognition, emotion and interpersonal relationship $(\mathrm{P}<0.05)$; special education teachers as class teacher get the lower scores than those not serving as class teacher on appraisal support, leisure sports and interpersonal support, but no significant differences exist "Table V".

TABLE V. ANALYSIS ON THE DifFERENCE OF HEALTHY BEHAVIOR, APPRAISAL SUPPORT AND DEPRESSION OF SPECIAL EDUCATION TEACHERS ABOUT WHETHER THEY ARE ClASS TEACHER

\begin{tabular}{|c|c|c|c|c|c|}
\hline \multicolumn{2}{|c|}{ Class teacher or not } & $\mathbf{N}$ & $\mathbf{M}$ & SD & $\mathbf{t}$ \\
\hline \multirow[t]{2}{*}{ Appraisal support } & Yes & 92 & 3.86 & 0.83 & -1.037 \\
\hline & No & 118 & 3.97 & 0.76 & \\
\hline \multirow[t]{2}{*}{ Leisure sports } & Yes & 92 & 3.54 & 0.95 & -0.622 \\
\hline & No & 118 & 3.63 & 0.98 & \\
\hline \multirow{2}{*}{$\begin{array}{l}\text { Interpersonal } \\
\text { support }\end{array}$} & Yes & 92 & 3.57 & 0.99 & -0.742 \\
\hline & No & 118 & 3.67 & 0.95 & \\
\hline \multirow[t]{2}{*}{ Cognition } & Yes & 92 & 1.98 & 0.59 & $2.406^{*}$ \\
\hline & No & 118 & 1.79 & 0.53 & \\
\hline \multirow[t]{2}{*}{ Emotion } & Yes & 92 & 2.30 & 0.87 & $2.113^{*}$ \\
\hline & No & 118 & 2.06 & 0.68 & \\
\hline \multirow[t]{2}{*}{ Body } & Yes & 92 & 2.56 & 0.82 & 1.599 \\
\hline & No & 118 & 2.08 & 0.77 & \\
\hline \multirow{2}{*}{$\begin{array}{l}\text { Interpersonal } \\
\text { relationship }\end{array}$} & Yes & 92 & 2.18 & 0.93 & $2.040^{*}$ \\
\hline & No & 118 & 1.92 & 0.92 & \\
\hline
\end{tabular}

f) Analysis on the differences of healthy behavior, appraisal support and depression of special education teachers with different positions: Check the independent sample $t$ with different positions as the independent variable, the healthy behavior, appraisal support and depression as the dependent variables. The results show special education teachers engaging in administration in part time get higher scores than those not engaging in administration on appraisal support, leisure sports and interpersonal relationship, significant differences exist on appraisal support and 
interpersonal relationship $(\mathrm{p}<0.05)$. The special education teachers engaging in administration in part time get lower scores than those not engaging in administration on interpersonal support, cognition, emotion and body, and significant differences exist on cognition and body $(\mathrm{p}<0.05)$ "Table VI".

TABLE VI. ANALysis ON THE DifFERENCES OF HEALTHY BEHAVIOR, APPRAISAL SUPPORT AND DEPRESSION OF SPECIAL EDUCATION TEACHERS WITH DIFFERENT POSITIONS

\begin{tabular}{|c|c|c|c|c|c|}
\hline \multicolumn{2}{|c|}{ Position } & $\mathbf{N}$ & $\mathbf{M}$ & SD & $\mathbf{t}$ \\
\hline \multirow[t]{3}{*}{ Appraisal support } & Special education teachers & & & & \\
\hline & handling administrative affairs & 43 & 4.20 & 0.66 & $2.892 *$ \\
\hline & Special education teachers & 167 & 3.85 & 0.81 & \\
\hline \multirow[t]{3}{*}{ Leisure sports } & Special education teachers & & & & \\
\hline & handling administrative affairs & 43 & 3.63 & 0.94 & 0.291 \\
\hline & Special education teachers & 167 & 3.58 & 0.97 & \\
\hline \multirow[t]{3}{*}{ Interpersonal support } & Special education teachers & & & & \\
\hline & handling administrative affairs & 43 & 3.57 & 0.66 & -0.375 \\
\hline & Special education teachers & 167 & 3.63 & 0.81 & \\
\hline \multirow[t]{3}{*}{ Cognition } & Special education teachers & & & & \\
\hline & handling administrative affairs & 43 & 1.75 & 0.50 & -1.630 \\
\hline & Special education teachers & 167 & 1.90 & 0.58 & \\
\hline \multirow[t]{3}{*}{ Emotion } & Special education teachers & & & & \\
\hline & handling administrative affairs & 43 & 2.04 & 0.59 & $-1.407 *$ \\
\hline & Special education teachers & 167 & 2.20 & 0.82 & \\
\hline \multirow[t]{3}{*}{ Body } & Special education teachers & & & & \\
\hline & handling administrative affairs & 43 & 2.01 & 0.56 & $-1.765^{* *}$ \\
\hline & Special education teachers & 167 & 2.20 & 0.85 & \\
\hline \multirow[t]{3}{*}{ Interpersonal relationship } & Special education teachers & & & & \\
\hline & handling administrative affairs & 43 & 2.85 & 0.67 & $-1.752 *$ \\
\hline & Special education teachers & 167 & 2.05 & 0.98 & \\
\hline
\end{tabular}

g) Analysis on the difference in healthy behavior, appraisal support and depression of special education teachers with different education backgrounds: Check the independent sample $t$ with different education backgrounds as the independent variable, the healthy behavior, appraisal support and depression as the dependent variables. The results show special education teachers with college degree and above on leisure sports and interpersonal support, but no significant differences exist. The special education teachers with college degree and below get lower scores than those with bachelor degree or above on appraisal support, cognition, emotion, body and interpersonal relationship, and significant differences exist on the appraisal support and emotion $(\mathrm{p}<0.05)$ "Table VII".

TABLE VII. ANALYSIS ON THE DiFFERENCE IN HEALTHY BEHAVIOR, APPRAISAL SUPPORT AND DEPRESSION OF SPECIAL EDUCATION TEACHERS WITH DIFFERENT EDUCATION BACKGROUNDS

\begin{tabular}{|c|c|c|c|c|c|}
\hline & ducation background & $\mathbf{N}$ & $\mathbf{M}$ & SD & $\mathbf{t}$ \\
\hline \multirow[t]{2}{*}{ Appraisal support } & College degree and below & 61 & 3.76 & 0.91 & $-1.78^{* *}$ \\
\hline & Bachelor degree or above & 149 & 3.99 & 0.73 & \\
\hline \multirow[t]{2}{*}{ Leisure sports } & College degree and below & 61 & 3.63 & 0.97 & 0.390 \\
\hline & Bachelor degree or above & 149 & 3.57 & 0.97 & \\
\hline \multirow[t]{2}{*}{ Interpersonal support } & College degree and below & 61 & 3.71 & 0.87 & 0.877 \\
\hline & Bachelor degree or above & 149 & 3.58 & 1.00 & \\
\hline \multirow[t]{2}{*}{ Cognition } & College degree and below & 61 & 1.84 & 0.59 & -0.591 \\
\hline & Bachelor degree or above & 149 & 1.89 & 0.56 & \\
\hline \multirow[t]{2}{*}{ Emotion } & College degree and below & 61 & 1.98 & 0.57 & $-2.645^{* *}$ \\
\hline & Bachelor degree or above & 149 & 2.24 & 0.84 & \\
\hline \multirow[t]{2}{*}{ Body } & College degree and below & 61 & 2.08 & 0.71 & -0.883 \\
\hline & Bachelor degree or above & 149 & 2.19 & 0.83 & \\
\hline \multirow[t]{2}{*}{$\begin{array}{l}\text { Interpersonal } \\
\text { relationship }\end{array}$} & College degree and below & 61 & 1.84 & 0.56 & -1.971 \\
\hline & Bachelor degree or above & 149 & 2.11 & 0.95 & \\
\hline
\end{tabular}

B. Correlation Analysis On The Appraisal Support, Healthy Behavior And Depression Of Special Education Teachers

The results show the appraisal support has significant positive correlation with leisure sports as well as interpersonal support $(\mathrm{p}<0.05)$; has significant negative correlation with cognition and emotion $(\mathrm{p}<0.05)$; the leisure sports have significant negative correlation with cognition, emotion, body and interpersonal relationship $(\mathrm{p}<0.05)$; the interpersonal support has significant negative correlation with cognition, emotion, body and interpersonal relationship $(\mathrm{p}<0.05)$; the subjective well-being has significant positive correlation with appraisal support, leisure sports and interpersonal support $(\mathrm{p}<0.05)$, has significant negative correlation with cognition, emotion, body and interpersonal relationship $(\mathrm{p}<0.05)$ "Table VIII". 


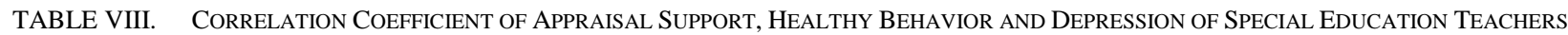

\begin{tabular}{|c|c|c|c|c|c|c|c|}
\hline App & aisal support & Leisure sports & Interpersonal support & Cognition & Emotion & Body & Interpersonal relationship \\
\hline Appraisal support & 1 & & & & & & \\
\hline Leisure sports & $.23 * *$ & 1 & & & & & \\
\hline Interpersonal support & $.171 * *$ & $.487 * *$ & 1 & & & & \\
\hline Cognitio & $-.236 * *$ & $-.255^{* *}$ & -.329 & 1 & & & \\
\hline Emotion & $-.176 * *$ & $-.283 * *$ & $-.307 * *$ & $.662 * *$ & 1 & & \\
\hline Body & -.090 & $-.281 * *$ & $-.269 * *$ & $.571 * *$ & $.656^{* *}$ & 1 & \\
\hline Interpersonal relationship & -.105 & $-.283 * *$ & $-.321 * *$ & $.600 * *$ & $.537 * *$ & $.537 * *$ & 1 \\
\hline
\end{tabular}

C. Analysis on the Direct Effect of Special Education

Teachers' Healthy Behavior and Appraisal Support on

Depression

According to the analysis on structural model, regardless of the subjective well-being, the value of direct effect of the healthy behavior on depression, the value of direct effect of the appraisal support on depression are -.33 and -.06 "Fig. 1", both of which reach the significant level $(p<0.001)$. The fitting index of other structural model also meets the statistical standards. See details in "Table IX".

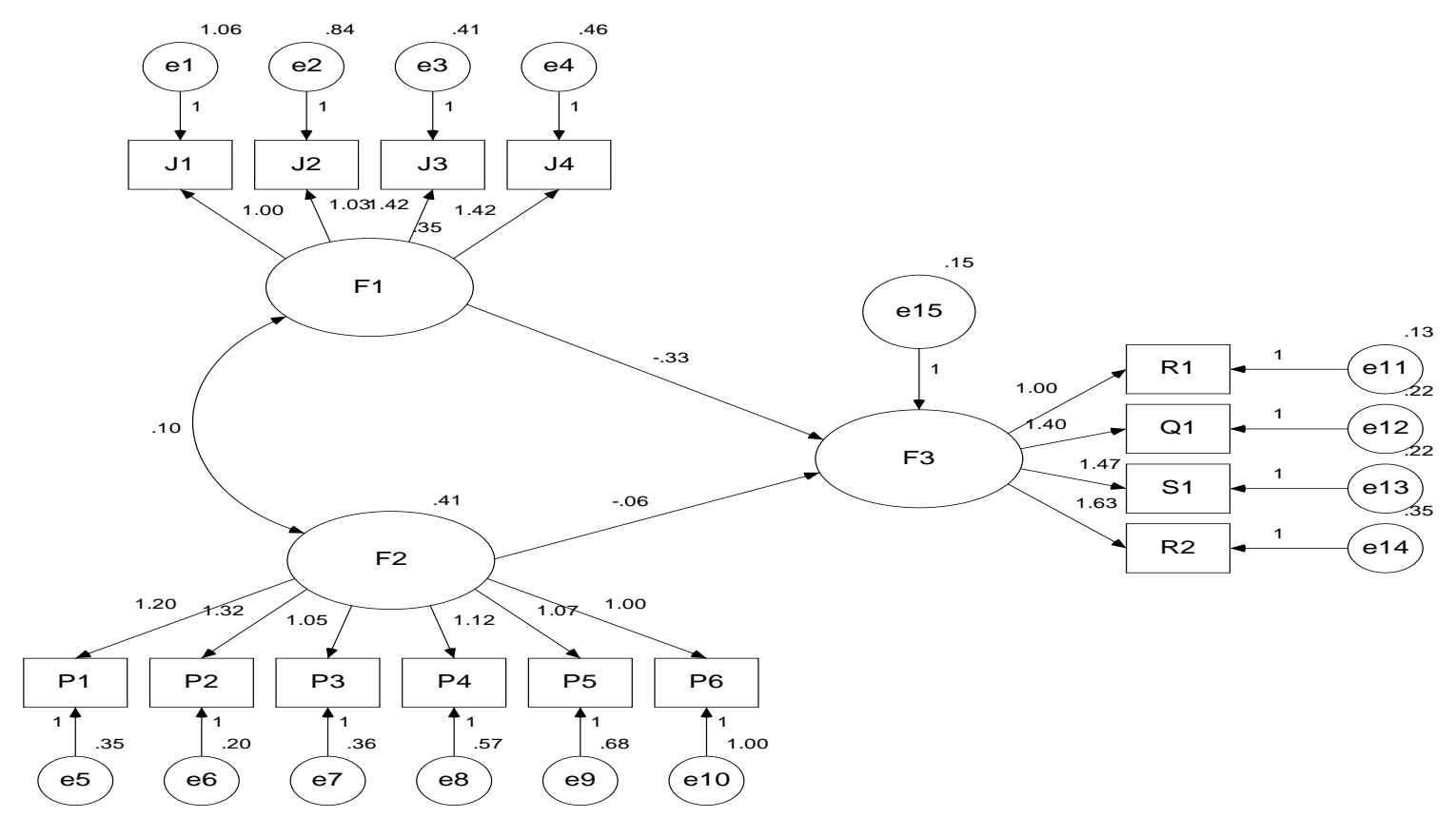

Fig. 1. Structural model diagram of special education teachers' depression, healthy behavior and appraisal support.

\section{DISSCUSSION}

\section{A. Analysis on the Characteristics of Special Education Teachers' Healthy Behavior, Appraisal Support and Depression}

In regard to the characteristics of special education teachers' healthy behavior, the research results show significant differences exist in the years of teaching experience. The score of leisure sports obtained by special teachers with experience of less than five years, more than eleven years as well as between six and ten years decreases in turn. Besides, significant differences exist between them. The development
TABLE IX. INDEX VALUE OF STRUCTURAL MODEL ADAPTATION DEGREE OF SPECIAL EDUCATION TEACHERS' HEALTHY BEHAVIOR, APPRAISAL SUPPORT AND DEPRESSION

\begin{tabular}{lllllcc}
\hline X2 & df & X2/df & GFI & NFI & CFI & RMSEA \\
\hline $288.8^{* * * *}$ & 74 & 3.903 & .825 & .802 & .843 & .085 \\
\hline
\end{tabular}

Note: F1 refers to healthy behavior; F2 refers to appraisal support and F3 refers to depression of special education teachers goes through three stages, namely concern about survival, concern about teaching situation and concern about self-development. [8] Teachers will accumulate teaching experience with the increase of years of teaching. They will get increasingly familiar with the teaching contents and spend less time in teaching the same contents. At this stage, teachers will pay attention to their physical and psychological health, spending more time in leisure sports. Therefore, teachers with experience of above eleven years often get higher scores than those with experience of six to ten years. Special education teachers with experience of less than five years get the highest score in leisure sports. It shows the new special education teachers need a transition time from students 
to teachers. Most of them are absorbed in the state of college days, spending plenty of time in leisure sports and making friends. Therefore, special education teachers with experience of less than five years get higher scores than those with experience of more than eleven years.

In regard to the characteristics of special education teachers' appraisal support, the research results show the special education teachers' appraisal support has significant differences in sex, position and education background. On the sex, male special education teachers get higher scores than the female in the appraisal support, showing it is more possible for the male to get the recognition of the leaders, colleagues and students and obtain higher appraisal. It is because the male is more rational than the female. They can solve the emergencies in teaching, scientific research and daily life more reasonably and achieve better effects. Therefore, the appraisal support of male special education teachers is significant higher than the female. On the position, special education teachers handling administrative affairs in part time get higher scores in appraisal support than those not engaging in administration. It shows the former are easier to gain praise and affirmation of leaders, colleagues and students' parents, because the former have rich teaching experience and they can properly use the resources and do a familiar job with ease in teaching and administration. On the education background, special education teachers with bachelor degree or above get higher scores in the appraisal support than those with college degree and below. It shows teachers with higher education background have richer professional knowledge, use it to teach and manage and get sound results and the attention of leaders.

In regard to the characteristics of special education teachers' depression, the research shows the depression of special education teachers is below the average level. Besides, significant differences exist in sex, years of teaching experience, the possibility of class teacher, position and education background. Male special education teachers get higher scores in body dimension than the female, showing the male are easier to feel uncomfortable. In the dimensions of cognition, emotion and body, teachers with experience of six to ten years get higher scores than teachers with experience of more than eleven years and less than five years. It shows the years of teaching experience have direct relationship with special education teachers' depression. Special education teachers as class teacher get higher scores than those not serving as class teacher in cognition, emotion and interpersonal relationship. Except for the teaching, the class teachers are also responsible for the class construction, class discipline and students' code of conduct. They bear heavier work stress than those not serving as class teacher, so problems in depression, cognition, emotion and interpersonal relationship appear more easily. On the position, special education teachers handling administrative affairs get higher scores than those not engaging in the administration in the interpersonal relationship. It shows the former has less time to do sports and get together with friends and family members, so the problem in interpersonal relationship appears more easily. No significant differences exist in the depression of special education teachers with different monthly income and martial status.

\section{B. The Relationship among Special Education Teachers' Healthy Behavior, Appraisal Support and Depression and Its Practical Significance}

According to the results of correlation analysis and the analysis on structural equation model, it shows the healthy behavior of special education teachers has significant predictive power for the depression degree. That is to say, the higher the frequency of special education teachers' healthy behavior, the lower the depress degree will be, conforming to the related research results. [9] With health responsibility, regular exercise habit, better ways to deal with stress, more interpersonal supporters, the individuals can experience the positive emotion in life more easily and have lower depression level. The research also proves the healthy behavior can improve the physical function, cut the death rate and reduce the risk of chronic disease, and has positive influence on individual's mentality and social life. In the research on the relationship between the participation of retired elderly people in leisure activities and their happiness, Li Weiling proposes the participation in social and leisure activities can reduce individual's depression risk. [10]

The results of correlation analysis and the analysis on structural equation model also show the scores obtained by special education teachers in the appraisal support have significant predicative power on the depression degree, corresponding to the related research results. [11] The analysis results of structural equation model show the high scores obtained by special education teachers in appraisal support can predict the low degree of depression. Generally speaking, with the evaluation of others especially the positive evaluation, individuals can feel the positive feedback, praise and affirmation, lowering the depression degree.

\section{CONCLUSION}

Teachers have always been the high risk group of job burnout. Special education teachers are the first to be affected because their job is special and arduous. At present, an increasing number of special education teachers suffer from the depression, which not only directly influences their physical and psychological health and work efficiency but also influences the growth of exceptional children. It is in urgent need of attention and response. The theoretical analysis shows the healthy behavior and appraisal support can effectively prevent and reduce teachers' depression. Therefore, it is necessary for schools to pay attention to and promote teachers' physical and psychological health from two aspects. On one hand, encourage teachers to participate in healthy activities like shopping, reading, seeing movies and listening to the music, and physical exercises like jogging, ball games, aerobic exercise and yoga; meanwhile, encourage them to get together with families or friends to make them feel happy and satisfied about the life quality. On the other hand, design related courses to teach teachers how to give the positive feedback and support to colleagues, encourage students and their parents to give proper affirmation to teachers so as to let teachers establish good self-evaluation. Furthermore, the relevant departments or schools shall also encourage teachers to participate in the training in order to strengthen their professional self-efficacy and continuously improve their positive self-evaluation. The 
realization of effective strategy to promote and protect teachers' psychological health needs the joint efforts of teachers, schools and relevant departments.

\section{REFERENCES}

[1] House, J. S.Work stress and social support.Reading, MA: AddisonWesley, 1981.

[2] Ho, D. Y. F.Interpersonal relationships and relationship dominance: An analysis based on methodological relationalism. Asian Journal of Social Psychology, 1998,1(1), 1-16.

[3] Biddle, S. J. H., Fox, K. R., \& Boutcher, S. H.Physical activity and psychological well-being. London: Routledge, 2000.

[4] Hardman, A. E., \& Stensel, D. J.Physical activity and health: The evidence explained. London: Routledge,2003.

[5] Janke, M. G., Nimrod, G., \& Kleiber, D. A. Leisure activity and depression symptoms of widowed and married women in later life. Journal of Leisure Research,2008, 40(2), 250-266.

[6] Lin Youzhen, Wen Qibang, Wei Peiwen. Discussion on the Relationship among Adults' Leisure Behavior and Healthy Behavior, Health Condition and Quality of Life Related to the Health in Taiwan [J], Taiwan Weizhi, 26(3): 218-228

[7] Min-Ning Yu, Yu-Ju Liu, Ren-Hau Li, the Practical Usage of Cutoff Score in the Taiwanese Depression Scale [J], Journal of Educational Research and Development, 2008, 4(4), 231-257

[8] Zhang Dabian, editor-in-chief, Educational Psychology [M], Beijing: People's Education Press, 1999, 340-341

[9] Tang Peiling, Chen Wenling. Discussion on the Depression Degree of Paramedic and Related Elements [J], Formosa Journal of Mental Health, 2005, 18 (2), 55-74

[10] Li Weiling. Research on the Participation of Retired Elderly People and Their Happiness [J], Journal of Humanities and Social Sciences, 2007, $3(2), 27-35$

[11] Shen Renhong, Li Xin. Research on the Psychological Health and Social Support of Special Education Teachers in Chongqing City [J], Chinese Journal of Special Education, 2007, (6): 2-8. 